to teach is the lack of an adequate way of describing them. Because learning with LOGO is learning within a descriptive system, it makes everything explicit and thus automatically more communicable.

That is the rationale for an experimental LOGO course which Ben du Boulay has been running at a local college for trainee primary school teachers. Primary school mathematics teaching is often a special problem partly because the teachers' own grip on the subject is none too firm. The aim of du Boulay's part of the Edinburgh project is to see whether LOGO learning has a function in helping primary teachers both to understand and to explain mathematics. That research is still at a preliminary stage.

But LOGO learning as a "catalyst" to communication is an important theme of the Edinburgh research. The particular term catalyst has been adopted by Sylvia Weir to describe the effect of LOGO learning on communications between an autistic child and the normal adults who work with him. Weir, working with Ricky Emmanuel, has found that allowing an autistic child to control the turtle from an array of buttons on a box stimulated him to communicate with them in a spontaneous way they had rarely seen in any other context.

She attributes this "humanising" effect to what she calls "shared relevance": the transparent connections between the pressing of the buttons and the movements of the turtle, and between the turtle's actions and the child's own movements in space provide, in her view, a basis of shared relevance, or a common framework, within which the child and the adults can communicate. Building on a framework of shared knowledge is the basis for any intelligent and effective teaching, and educationists acknowledge that good teaching must depend on the teacher's being able to reach out to the child's position and lead him from there. LOGO learning may be a special help where the subnormality of the child makes the gap unusually large and the teacher's task unusually difficult.

\section{Future of LOGO}

But the commitment of the Edinburgh group is to find hard evidence for the possible benefits of computerbased teaching systems like LOGO. Most of the known methods of educational assessment will be used for that purpose, and Howe and O'Shea have added one new test specially designed to reflect some of the skills that LOGO is supposed to promote. O'Shea calls it the "articulation test", and it tests the ability of a child sitting on one side of an opaque screen to instruct his partner on the other side on how to construct a particular pattern from coloured blocks. That apparently simple problem has been known to reduce an untutored child to tears of inarticulate frustration, so the results should be interesting; but so far, they are only suggestive.
On what evidence there already is, what part are computer-based systems really likely to play in future education? Papert purports to believe that the future of education and computerbased systems are one and the same, and the next few decades will see the day when each child sits at home at his own computer terminal, without going to school at all. Expense he shrugs off on the grounds that electronics, unlike anything else, are getting exponentially cheaper (consider the cost of the pocket calculator five years ago and now). Nonetheless, equipment of any kind is expensive and computers and their peripherals will remain more expensive than books. And although the Edinburgh research team has been impressed by the way that Papert's educational insights have been borne out, from the practical point of view their attitude is both more conservative and more pragmatic than his.

First, they do not see in LOGO a means of disposing of the teacher: the idea is that such systems may make conventional teaching methods more effective, not that they should replace them. Second, experience is beginning to suggest that the most effective use of computer systems may turn out to be in the education of subnormal children or those with other special problems. If the Edinburgh group can be accused of having a vision, then it is of machines which foster human interactions, rather than making them obsolete.

\title{
BRITAIN
}

\section{Benn spells it out}

Developments on the British energy

front are fast and furious, with nuclear power capturing most attention. Chris Sherwell reports.

FAST moving sectors of the British economy are not in great abundance these days, but there is one that is beginning to behave in a manner representative of a seething hive of activity. Hardly surprising, for it is none other than the energy sector itself. And not a little of this is due to the increasingly voluble debate over nuclear power.

The arguments over whether Britain should have nuclear power already having been settled, the manner in which it is to be deployed and utilised is now at issue. That includes the question of timing, so there are tactical as well as strategic policy decisions to be taken. The latest involves the Steam Generating Heavy
Water Reactor (SGHWR), expenditure on which was deferred for a year in the latest round of government spending cuts.

The cut means a saving for 1977-78 of $£ 40$ million, and a reduction of $£ 5$ million on research for the project. That in turn has made the broadening debate on the future of the SGHWR either more pointless or more controversial, depending on your perspective. But it hasn't prevented a start to the hearings of the House of Commons Select Committee on Science and Technology on the subject. They began this week, Mr Anthony Wedgwood Benn, Secretary of State for Energy, answering questions.

Mr Benn was fresh from his discussions at the end of last week with Sir Arthur Hawkins, chairman of the Central Electricity Generating Board (CEGB), who supported the pressurised water reactor when a choice was being made in Britain in 1974 but has since, on $\mathrm{Mr}$ Benn's testimony, given every assistance regarding the SGHWR. Sir Arthur was, however, expected to deploy cost estimates and electricity demand forecasts to advise against an immediate go-ahead, on the SGHWR or anything else. $\mathrm{Mr}$ Benn also had before him a report submitted within the past week from Sir John Hill, chairman of the UK Atomic Energy Authority (UKAEA), assessing the progress made so far on the SGHWR.

It was soon apparent that $\mathrm{Mr}$ Benn was concerned to make only four main points. One, as he pointed out at the beginning, the middle and the end of his evidence, the British Government has not yet reached a decision to cancel the SGHWR, nor even a preliminary view on the matter. Two, the decision through spending cuts to postpone for a year its commissioning, while possibly having consequences for the nuclear industry outside the SGHWR programme, was the product of deferment presenting itself as an option. This was in turn a result of "natural slippage" on the SGHWR's reference design and safety standards working in the same direction as the effect of 
falling demand for power stations on energy forecasts.

Third, the initiative which resulted in the circumstances under which the SGHWR was now under scrutiny lay not with the government but with the UKAEA. Sir John Hill had approached Mr Benn and given his view on the SGHWR; Mr Benn had asked him to put this before the UKAEA board for its considered judgment, and that had been done.

It was this, in fact, which made the hearing the more revealing, for the report itself was actually supplied to the committee by Mr Benn before the hearings and was used as a basis for questioning Mr Benn. Inevitably, some of its details came tumbling out.

The UKAEA's view, it emerges, is that, because of lower electricity demand and public expenditure stringency, the SGHWR is less attractive than it was two years ago. The "consensus view" of the board is, with the exception of the historically enthusiastic South of Scotland Electri- city Board, that the SGHWR be replaced for the remaining thermal reactor programme by Pressurised Water Reactors (PWRs) or Advanced Gas Cooled Reactors (AGRs)-and that the AGR is the more promising, although operational experience is needed.

The UKAEA went further than this. Subject to a satisfactory outcome of the Nuclear Inspectorate's review of the PWR, there was a "strong argument" that the future needs of the nuclear industry could be met by the construction of PWRs under licence. This, Mr Benn freely acknowledged, would, if acted upon, constitute a reversal of the government's decision taken two years ago when his predecessor, Mr Varley, was at the Department of Energy. And, he said later, in the field of high technology one shouldn't "chop and change" once a decision was taken; he added reassuringly that he himself was "reluctant to be driven off".

The precise extent of his reluctance was twice made quite plain when he made his fourth point. This outlined his response thus far to the UKAEA, and it amounts to a warning. If the SGHWR programme is dropped, says $\mathrm{Mr}$ Benn, it could be a setback to the country's whole reactor programme. A decision to go for the PWR would mean re-commencing the whole effort to produce a reference design to meet UK conditions, and thus more delays, and even then it would not certainly provide a solution. It would also set aside the past two years' work, and previous work carried out at Winfrith in Dorset.

Moreover, this would amount to a statement from the UKAEA that it had lost confidence in its own system. That would in turn rebound and damage the credibility not just of the UKAEA, but of the systems it sponsors, including the fast breeder, and of the whole nuclear idea. The nuclear issue, in short, might be thrown right back into the public arena, "where it may belong".

\section{FRANCE}

\section{Staying nuclear}

France's nuclear programme has come in for some domestic criticism recently, but looks like pressing ahead. A Correspondent reports

IT is August, France is on holiday, and that has brought a degree of quiescence to town and country. There is even time for some sort of break from politics, or at least from certain political issues. But it remains uncertain whether, come September, one issue in particular will have been allowed completely to die away. The issue is energy - specifically nuclear energy. Specifically the fast breeder reactor. For, despite all the impressions conveyed abroad, the priority France gives to her nuclear programme in her overall energy strategy does not go totally unchallenged. And the priority given within that to the breeder reactor has not escaped attention.

The whole issue finally blew up early last month, at a place called CreysMalville, which is near Lyons and on the Rhône. Under construction there is perhaps the most advanced reactor of its type in the world. Superphénix, it is called, and it is expected to be on stream in the early 1980s-all 1,200 MW of it. Like Britain, France already has a prototype breeder reactor, a 250 MW plant known as Phénix situated on the Rhône at Marcoule. But while Britain agonises about whether to go ahead with a demonstration commercial-scale breeder, France is on her way-or looked to be until last month, when there was a new development.

It was Europe's anti-nuclear lobby which stepped in. Superphénix, already the object of trade union protests, became the butt of criticism from ecologists and environmentalists as well. They came in hundreds and camped outside the site where workmen toiled. The jamboree lasted several days. The way it was brought to an end, however, aroused even more indignation than perhaps the construction itself: riot police moved in with tear gas and truncheons to evict the demonstrators, and some of the protesters were hurt.

The criticism in France, as in other industrialised countries contemplating the use of the fast breeder reactor, is emotive inasmuch as it rides on the back of fear, particularly about the implications of the large-scale production of plutonium. It is not less rational, or less important, for that. But its form is characteristic. So, too, is the response from Electricite de France (EDF) and other interests within the French nuclear industry, and from the government too. Just look at France's energy position, they say.

Imports account for something like $75 \%$ of the country's energy requirements, a dependence which France must seek to reduce, if only for strategic reasons. What is more, the argument runs, unlike Britain, the country has no oil, and its coal reserves don't compare with those of Britain or Germany. That means nuclear power is likely to make economic sense as well. And the alternative threat of an energy shortage embodies implications as alarming as nuclear power for people's lives.

of course France, like other industrialised countries, has been forced to revise its energy demand forecasts in light of general economic developments. Energy use last year, for example, dropped by over $5 \%$, more than the fall in national product, and there is increasing emphasis on energy conservation. A fair amount of encouragement is also given to research and development on new sources of energy.

But no one seriously doubts that France needs nuclear power now and will need it even more in the future. Even a special commission examining energy policy in France, formed partly in response to concern expressed last year by 400 academics at the increasing use of nuclear power, has not recommended any slowdown. Following a review of the nuclear programme earlier this year plans for power capacity over the next few years includes construction of $6,000 \mathrm{MW}$ of nuclear power this year and next, and 5,000 MW in 1978. The change this represents on the original programme is marginal, and, despite the protests, the talk is still of $40,000-45,000 \mathrm{MW}$ of nuclear power 1985. By that time most of the country's electricity will be nuclear generated and a substantial proportion of its total energy will be coming from nuclear plants. 